Review article

Received: 25 Aug 2020

Revised: 13 Sep 2020

\title{
MONITORING PROPOSAL OF THE SPECIES Streptocephalus torvicornis (Waga 1842) IN POLAND
}

Faculty of Animal Breeding, Bioengineering and Conservation, Warsaw University of Life Sciences -SGGW, Warszawa, Poland

\begin{abstract}
The paper presents a proposal of methods for monitoring the species Streptocephalus torvicornis, which belongs to large branchiopods. This species occurs in small ephemeral water bodies. Currently, there is only one known locality of $S$. torvicornis in Poland. Many species of large branchiopods are considered to be in danger of extinction. Their observation in the environment is hampered by the periodic nature of the occurrence of adults. The proposed method of population status assessment is based on the analysis of soil samples in terms of the presence of persistent cysts. The following factors may be used to assess the condition of the habitat: the presence of vegetation indicating the astatic or ephemeral nature of the pools, the level of succession of trees and shrubs, the presence of fish, the presence of potential sources of pollution. The proposed methods are universal and can be applied to the monitoring of other large branchiopods species. Regular monitoring may contribute to the recognition of other places of occurrence and will enable effective protection of the species S. torvicornis in Poland.
\end{abstract}

Key words: Branchiopoda, cyst bank, monitoring methods.

\section{INTRODUCTION}

The aim of this study was to propose methods of monitoring the species Streptocephalus torvicornis, belonging to the large branchiopods.

\section{DESCRIPTION OF THE SPECIES}

Streptocephalus torvicornis is a representative of the Branchiopoda class. With a geographical range reaching from the Sahara through the Mediterranean region and central Europe all the way to the end section of the Volga River (Rogers 2013). In the entire area of its appearance it inhabits ephemeral and astatic water bodies. Despite a wide reach and the fact of inhabiting small-scaled isolated bodies of water, the world population of this species is relatively genetically homogenous (Kappas et al. 2017). It is assumed that the dispersal from Africa to Europe of many species of Branchiopoda occurred after the Würm III glaciation, so relatively recently (10 thousand years ago) which is the cause for the little differentiation

Corresponding author: Stanisław Cukier, Faculty of Animal Breeding, Bioengineering and Conservation, Warsaw University of Life Sciences - SGGW, Ciszewskiego 8, 02-786 Warszawa, Poland, e-mail: staszek.cukier@gmail.com 
(Dumont' et al. 1995; Zierold 2006). It is also possible to assume that the population's isolation is evident, and the gene flow is easy thanks to the transfer of cysts through birds associated with water biomes. Dormant cysts can also be transferred by air, water during flooding (Vanschoenwinkel et al. 2008; Schwentner et al. 2012)

Streptocephalus torvicornis belongs to the so-called large branchiopods. It is a group consisting of representatives Branchiopoda class with exception of water fleas (Cladocera). This group is believed to be one of the most threatened with extinction among freshwater invertebrates (Brendonck et al. 2008; Gołdyn et al. 2012, 2019). These crustaceans are characteristic for ephemeral water bodies. In the process of evolution, a mechanism developed in them allowing for the survival under harsh conditions, such as droughts. In the eggs laid by the females, larvae form which at a certain moment enter diapause while remaining in their egg coats. The cysts created by these means are able to survive aridifications and frosts. The cysts are also resistant to other factors such as UV radiation, mechanical damage, and toxic substances.

Representatives of the species Streptocephalus torvicornis grow up to a length of $3 \mathrm{~cm}$. They swim in the pelagic zone with their extremities facing upwards. They have a half-transparent body. From the outside visible are internal organs such as the bowel, ovaries in females, testicles in males. The cercopods are orange coloured, covered in setae. The filtering apparatus, with which they pick up food fragments, consists of setae located on endopodites, which are then covered in fine setae and thorns. Such a filtering apparatus allows to pick up bacteria and micro algae from the pelagic zone. Females bear brood pouch with a distinctive red stripe (Fig. 1). The II pair antennae in females are short and flattened. Males have enlarged and splitting II pair antennae. They each bear two penes. Their body has a slightly blue tone (Fig. 2). An important diagnostic characteristic is the existence of crenation on the I pair antennae in $1 / 3$ of the length in males (Maeda-Martinez and Dumont' 1995).

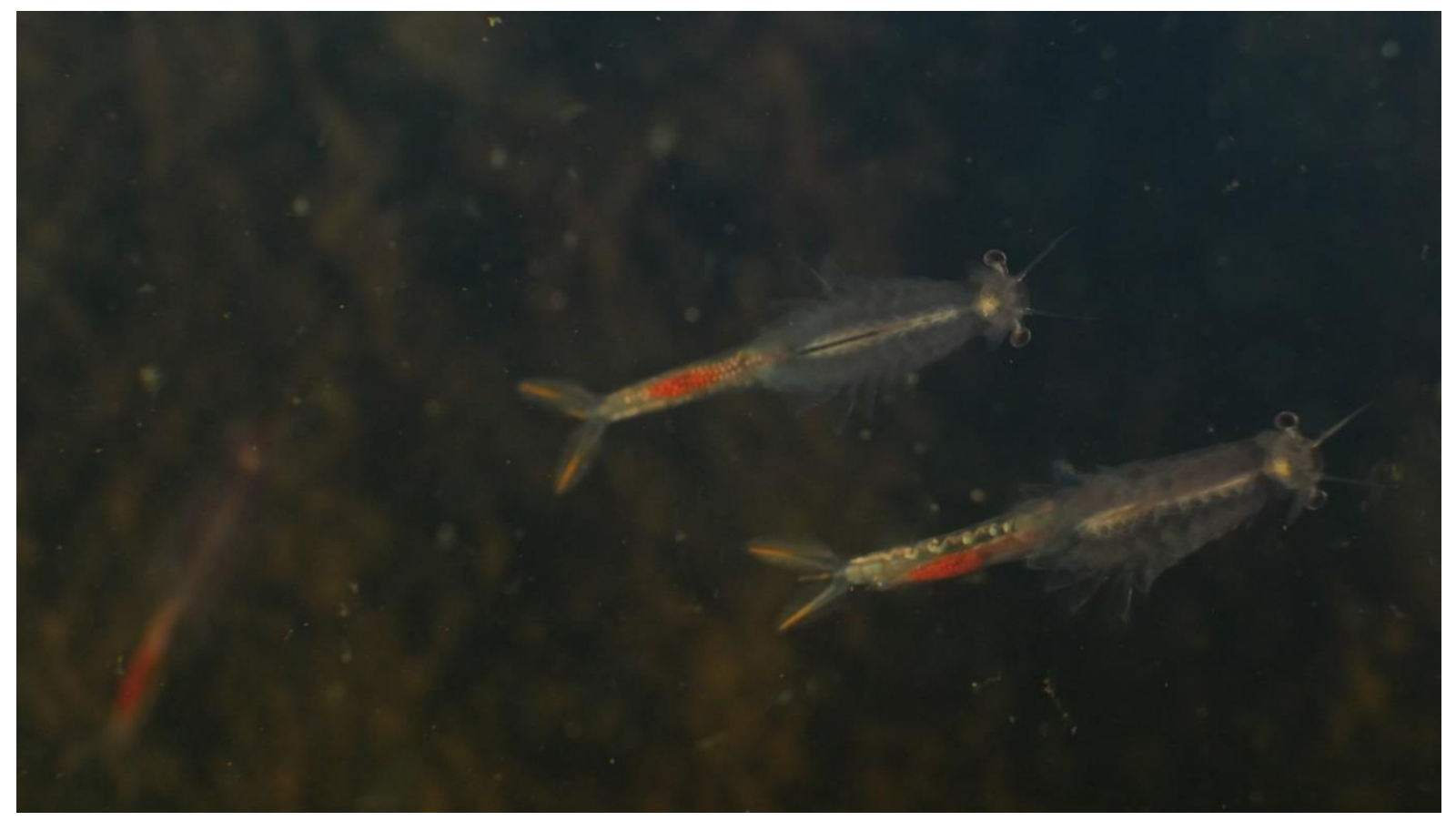

Fig. 1. Streptocephalus torvicornis females - ventral view (photo S. Cukier) 


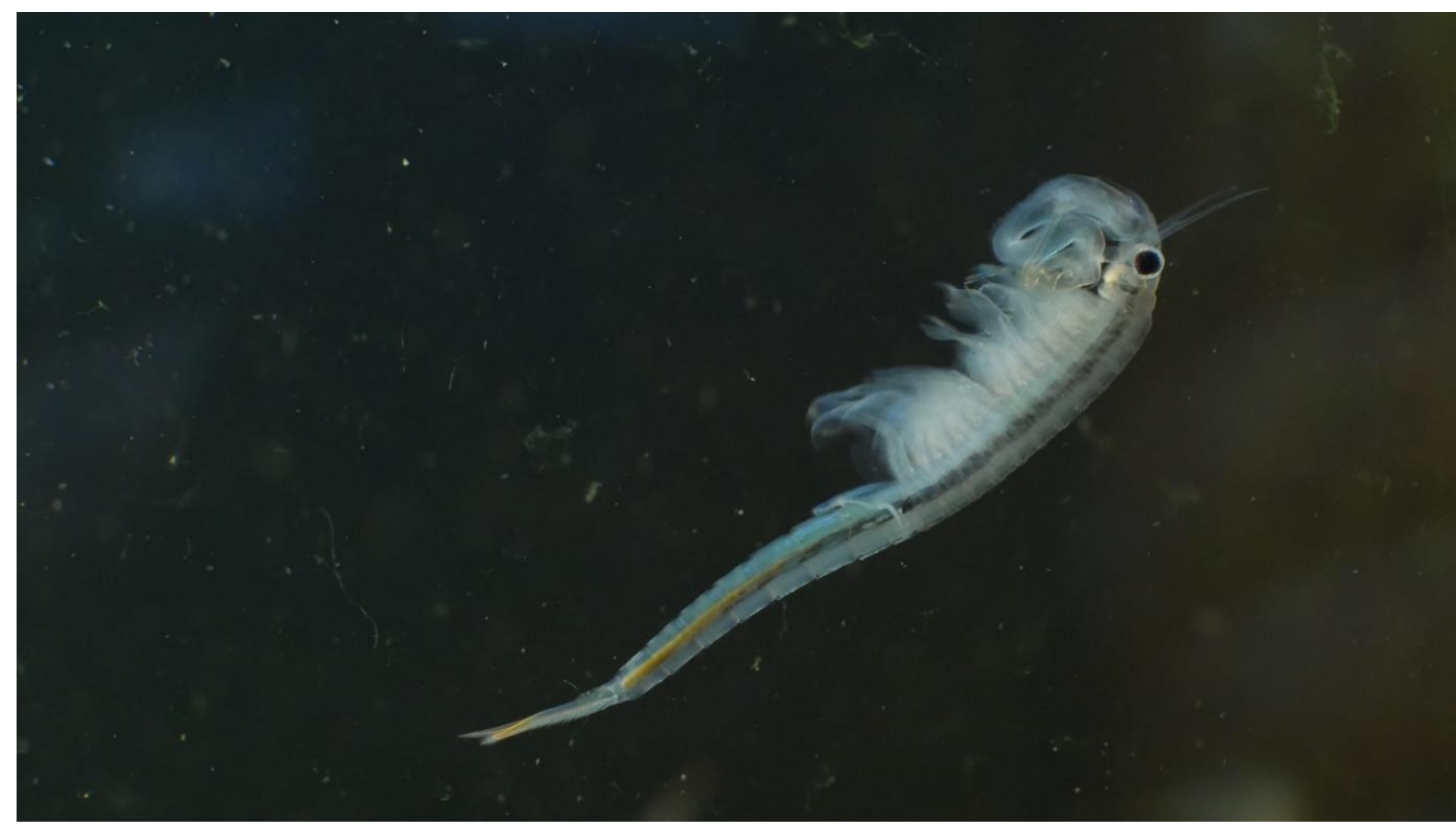

Fig. 2. Streptocephalus torvicornis male - side view (photo S. Cukier)

\section{BIOLOGY OF THE SPECIES}

In comparison to other larger branchiopoda, Streptocephalus torvicornis is a long-living species. In captivity males can even live up to 10 months. Females, on the other hand, live 120 days (Dumont and Munuswamy 1997). They reach sexual maturity on the 19th day of their life. They produce 74 cysts on average per female per day, in the period between the 40th and the 70th day of their life (Beladjal and Mertens 2003). During mating the males use the II pair antennae to hold the females. Females bear a pointed brood pouch in which the fertilization occurs. After fertilization, the embryos' development sets in and the egg coats harden. After about 2 days the female places the brood pouch in the ground and by opening the hole located on the brood pouch's end, it releases the eggs (Kraus et al. 2004). Next, after their development's halt, the eggs become cysts. The hatching of the larvae is inducted by such factors as, humidity, a high concentration of oxygen, sunlight. There are assumptions that the hatching of the larvae would be inhibited by the presence of pheromones secreted by adult specimen. Such a mechanism makes sense, since in a body of water flooded for a long time many predators appear for which the defenceless nauplii are an easy source of food (Mertens et al. 2007).

Ephemeral bodies of water inhabited by the representatives of Streptocephalus torvicornis are characteristic for a certain sort of ecological succession of organisms. First after the flooding of the body of water bacteria appear, then single-celled protozoans and algae. Bacteria most probably serve as the most important source of nourishment for the larvae of the discussed species. For adult specimen protozoans, algae and sediments of dead organic material have a greater importance. The larvae begin to hatch after the flooding of the cysts with clean water after about $24 \mathrm{~h}$ at a temperature of $25^{\circ} \mathrm{C}$. 


\section{HABITAT REQUIREMENTS}

The Streptocephalus torvicornis species inhabits astatic or ephemeral bodies of water (Fig. 3). Those are most often periodically flooding meadows, depressions in terrain in which water accumulates after spring thaws or after heavy rains. An existential condition is for sure the lack of natural predators or conditions strongly hampering hunting, e.g. low water transparency (Ramułt 1939). A key limitation for many predators, including predatory fish, is the periodic character of said bodies of water. Streptocephalus torvicornis can also be found in nursery ponds dedicated to the rearing of young fish (Dulina 2008; Cukier 2019). They are flooded for a period of about two months, typically from May to June. The discussed species prefers neutral water or slightly alkaline water from soft to hard, at a temperature from $15^{\circ} \mathrm{C}$ to $32^{\circ} \mathrm{C}$.

Companion species can be other large branchiopods, e.g. Triops cancriformis, Limnadia lenticularis (Cukier 2019), Branchipus schaefferi (Ramult 1939), as well as other crustaceans; copepods of the Diaptomus sp. and osctracods (Heterocypris incongruens) (the author's observations).

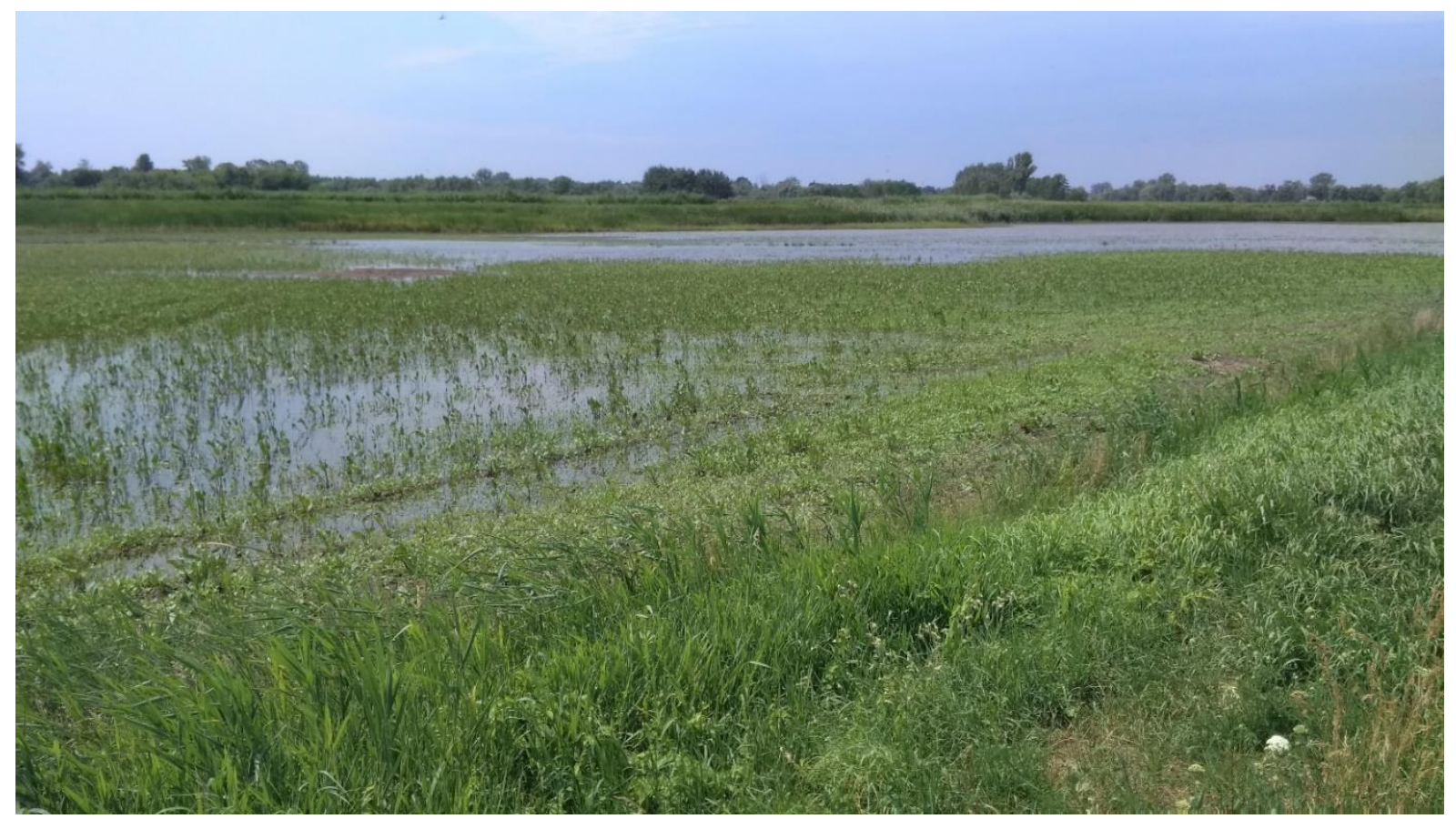

Fig. 3. Ephemeral water bodies (photo S. Cukier)

\section{DISTRIBUTION OF THE SPECIES IN POLAND}

There are two known historical locations in Poland where Streptocephalus torvicornis could be found (Fig. 4). One of them was a small water reservoir in a rustic garden in the village of Odolany (currently a neighbourhood of Warsaw Wola district) (Waga 1842). The specimen taken from this reservoir by Antoni Waga contributed to the first description of this species in 1842. Another location was a shallow ephemeral body of water in the western outskirts of Kraków. The last mentions in literature about the distribution of the discussed species in Poland are from 1939 (Ramułt 1939). In 2019 a new location was discovered by Cukier (2019) 
in the Fisheries Experiment Station Łąki Jaktorowskie in the municipality Jaktorów near Warsaw. It is currently the only known location of this species in Poland. The carp farm is functioning with a Dubish method thanks to which ephemeral water bodies are created for the rearing of young carps, which provide refugia for three species of large branchiopods, including Streptocephalus torvicornis (Cukier 2019). There is a possibility that the species could also be present in other fish farms. Yet, no scientific research was conducted on that subject.

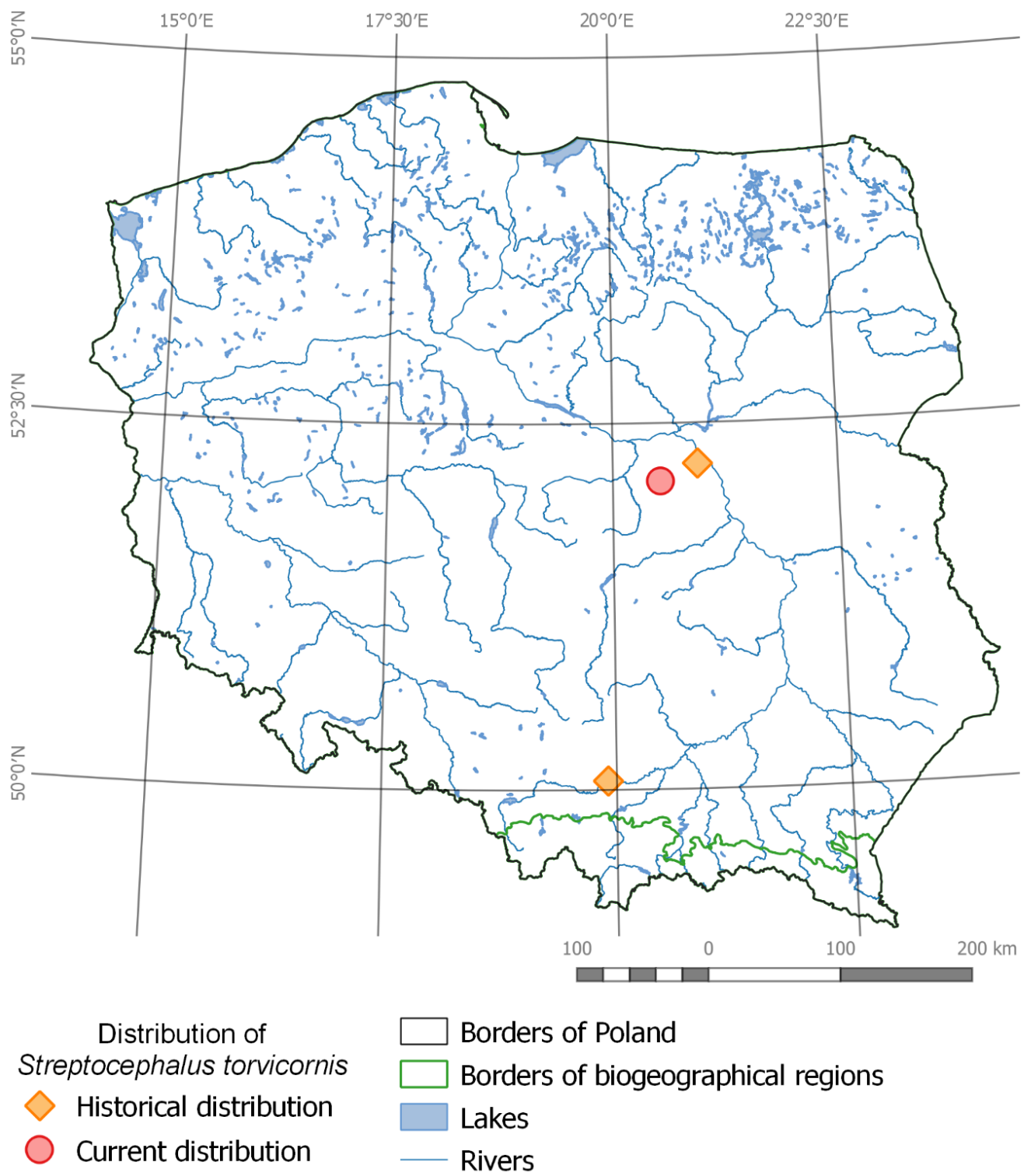

Fig. 4. Distribution of Streptocephalus torvicornis in Poland

\section{CONCEPT OF THE SPECIES MONITORING}

The evaluation method of the conservation status of Streptocephalus torvicornis and of the monitoring has an original character. A part of the methods was already tested in Fisheries Experiment Station Łąki Jaktorowskie, which is currently the only known location of its distribution. 
Due to the periodic appearance of adult forms of Streptocephalus torvicornis in a natural environment, the monitoring as well as the tests with the goal of finding new locations of distribution can prove difficult. The lack of adult forms of these crustaceans in the environment does not have to indicate a bad state of population. Therefore, the author of the method proposes an evaluation based on the dormant cyst bank's state. For the evaluation of the presence of the species in the given area, it is sufficient to take samples of the ground and check if they contain cysts of the discussed species. Because of the characteristic ornamentation on the egg coats (Fig. 5), it is possible to recognize some species of large branchiopods based on the cysts.(Czyż et al. 2016; Kappas et al. 2017). Yet, to rule out negative impacts of unknown factors, the vitality of the cysts should be tested as well. For that reason, the samples taken from the environment should be placed in conditions allowing for their further hatching and development.

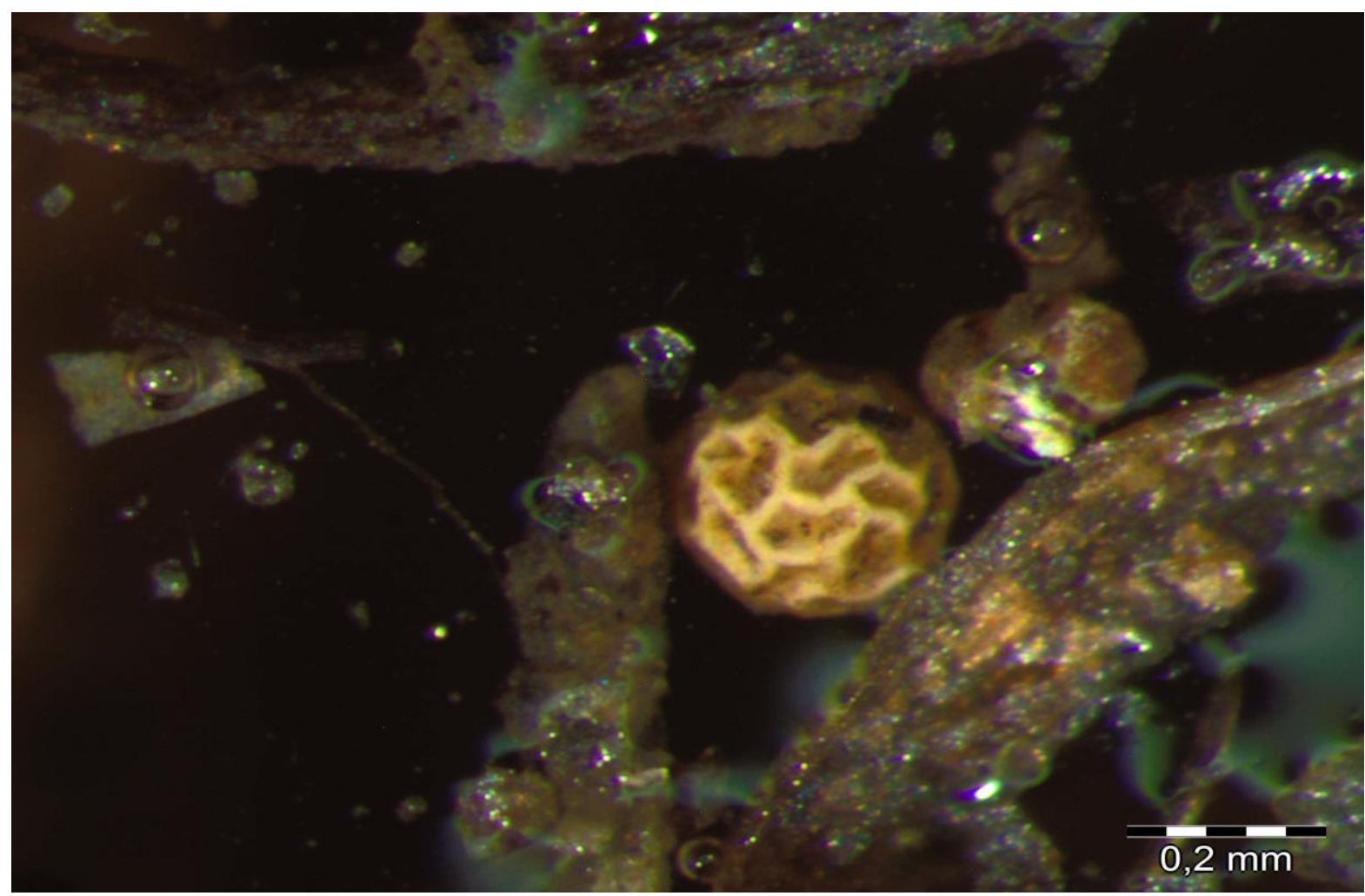

Fig. 5. Streptocephalus torvicornis cyst among the fragments of soil (photo S. Cukier)

In order to minimize negative impacts of reducing the natural bank of cysts in the given area, the operations should be carried out with highest accuracy and the collected specimen should be kept in laboratory conditions. The cysts laid by specimen in tanks should be cleaned, dried, and reintroduced into their natural environment. The author of this paper also recommends keep parts of the cysts and storing them in a cool and dry place with the goal of ex situ protection. Because of the invasive nature of the method, it should be conducted by experienced researchers. The place used for upkeep and cultivation should be clean. Because of the risk of contamination of the natural habitat with foreign species, it should be thoroughly disinfected before the procedure, and the cysts dedicated for inhabiting it should be thoroughly rinsed. 
The habitats with presence of the species Streptocephalus torvicornis in Poland are very poorly known. Yet, using the knowledge of other large branchiopods to assume conditions close to their natural environment, it is possible to exclude possible risks: land amelioration of agricultural and forestry areas, construction of dams and reservoirs, aridification of wetlands, development on flooding areas, overgrowth of flooding meadows, elimination of grassed water ponds in fields, change in the usage of carp farms, polluting emissions, annual fish stocking of stagnant water bodies, construction of permanent water bodies in areas with stagnant water bodies. That is why the evaluation of the state of habitat requires an evaluation of the periodic characteristics of the water bodies and pollution of the habitat. The prognosis of changes in the usage of areas in habitats of Streptocephalus torvicornis can be found of utmost importance for the evaluation of the perspectives of survival.

Simultaneously to the development of knowledge about Streptocephalus torvicornis, the methods should be updated and modified so monitoring would allow for better prognosis of risks and a more effective protection of the species.

\section{INDICATORS}

The assessment system is taken from the Methodology of nature monitoring (MakomaskaJuchiewicz 2010).

Indicators of the population's state are shown in Table 1.

Table 1. Indicators of the state of population of Streptocephalus torvicornis

\begin{tabular}{|c|c|c|}
\hline Indicator & Measurement & Way of evaluation \\
\hline Abundance & $\begin{array}{l}\text { number of cysts per unit } \\
\text { of ground mass }\end{array}$ & $\begin{array}{l}\text { Evaluated based on the number of cysts separated from } \\
\text { the samples of ground taken from the monitored area. The } \\
\text { places should be chosen by systematic drawing with } \\
\text { consideration of various specific conditions for the given } \\
\text { area. The samples of the ground should have a total mass } \\
\text { not below } 3 \mathrm{~kg}\end{array}$ \\
\hline Vitality of cysts & $\begin{array}{l}\text { percentage of hatched } \\
\text { larvae in comparison to } \\
\text { the number of cysts }\end{array}$ & $\begin{array}{l}\text { Evaluated by the number of hatched larvae after the } \\
\text { initiation of the hatching process through the flooding } \\
\text { of the prior separated cysts with water with the right para- } \\
\text { meters (conductivity from } 200 \mu \mathrm{S} \cdot \mathrm{cm}^{-1} \text { to } 600 \mu \mathrm{S} \cdot \mathrm{cm}^{-1} \text {, } \\
\text { temperature from } 20^{\circ} \mathrm{C} \text { to } 26^{\circ} \mathrm{C} \text { ) and the incubation } \\
\text { in a temperature of } 25^{\circ} \mathrm{C} \text { with simultaneous illumination. } \\
\text { The abundance should be evaluated } 48 \mathrm{~h} \text { after flooding }\end{array}$ \\
\hline
\end{tabular}

Adopted valorization of the status indicators of the population is presented in Table 2.

Table 2. Valorization of Streptocephalus torvicornis population status indicators

\begin{tabular}{|c|c|c|c|}
\hline Indicator & \multicolumn{3}{|c|}{ Evaluation } \\
\hline $\begin{array}{l}\text { Abundance } \\
\text { Vitality of cysts }\end{array}$ & $\begin{array}{c}\mathrm{U} 2 \\
<10 \mathrm{cyst} / \mathrm{kg} \\
<5 \%\end{array}$ & $\begin{array}{c}\text { U1 } \\
10-100 \text { cyst/kg } \\
5-20 \%\end{array}$ & $\begin{array}{c}\text { FV } \\
>100 \mathrm{cyst} / \mathrm{kg} \\
>20 \%\end{array}$ \\
\hline
\end{tabular}

The final assessment of the population's condition is determined by the lower of the assessments defined for individual indicators. Indicators of the habitat are shown in Table 3. 
Table 3. Indicators of the habitat of Streptocephalus torvicornis

\begin{tabular}{|c|c|c|}
\hline Characteristic & Measurement & Way of evaluation \\
\hline $\begin{array}{l}\text { Flora indicating an astatic or } \\
\text { ephemeral character of the } \\
\text { water body }\end{array}$ & descriptive assessment & $\begin{array}{l}\text { Determine whether species of plants characteristic } \\
\text { for stagnant water bodies are present in the area, } \\
\text { or species of plants characteristic for periodically } \\
\text { flooded meadows Molinion caeruleae and Cnidion } \\
\text { dubii }\end{array}$ \\
\hline $\begin{array}{l}\text { Succession of trees and } \\
\text { shrubs }\end{array}$ & $\%$ & $\begin{array}{l}\text { Evaluate percentage of overgrowth in the water } \\
\text { body by trees and shrubs }\end{array}$ \\
\hline Presence of fish & descriptive assessment & $\begin{array}{l}\text { Determine whether fish are present in the water } \\
\text { body based on fishing results, observation from } \\
\text { the shore or interviewing the users of the pond, } \\
\text { or fishers }\end{array}$ \\
\hline $\begin{array}{l}\text { The presence of potential } \\
\text { sources of pollution }\end{array}$ & descriptive assessment & $\begin{array}{l}\text { Determine the presence of public roads with } \\
\text { bitumen surface or industrial factories } \\
\text { intensive farms or numerous residential buildings } \\
\text { or other sources of pollution in a } 100 \mathrm{~m} \text { radius from } \\
\text { the area }\end{array}$ \\
\hline
\end{tabular}

Valorization of the habitat state are shown in Table 4.

Table 4. Evaluation of indicators of the habitat of Streptocephalus torvicornis

\begin{tabular}{lccc}
\hline \multicolumn{1}{c}{ Characteristic } & 0 & $\begin{array}{c}\text { Amount of points } \\
0.5\end{array}$ & 1 \\
\hline $\begin{array}{l}\text { Flora indicating an astatic } \\
\text { or ephemeral character } \\
\text { of the water body }\end{array}$ & $\begin{array}{c}\text { Lack of plants which } \\
\text { might indicate the } \\
\text { existence of a periodic } \\
\text { or a stagnant body of } \\
\text { water }\end{array}$ & $\begin{array}{c}\text { Present species } \\
\text { which might indicate } \\
\text { the existence of a } \\
\text { periodic or a stagnant } \\
\text { body of water }\end{array}$ & $\begin{array}{c}\text { Lack of or single } \\
\text { trees or shrubs } \\
(<10 \%)\end{array}$ \\
$\begin{array}{l}\text { Succession of trees and shrubs } \\
\text { Presence of fish }\end{array}$ & $\begin{array}{c}\text { Area heavily covered in } \\
\text { trees and shrubs }\end{array}$ & $\begin{array}{c}\text { Body of water with } \\
\text { present trees and } \\
\text { shrubs }(<20 \%)\end{array}$ & - \\
$\begin{array}{l}\text { The presence of potential } \\
\text { sources of pollution }\end{array}$ & Present & - & Missing \\
\hline
\end{tabular}

The sum of points for individual characteristics constitutes the value of the habitat quality index of Streptocephalus torvicornis. The following indexation was proposed:

$3,5-4-F V$ good,

$2.5-3-\mathrm{U} 1$ unsatisfactory,

$0-2.5-\mathrm{U} 2$ bad.

\section{PERSPECTIVE}

The conservation prospect assessment should include the current the population condition and the habitat condition. The landowners and users should also be interviewed to find out about the future use plans for the site of Streptocephalus torvicornis. valorization proposal: 
FV - Good prospects, high number of cysts per soil mass unit, high larval viability, large area where cysts are detected, habitat with features indicating the presence of periodic or astatic water bodies, use plans indicating continued maintenance of the same use methods for meadows and ponds carp.

U1 - prospects not very favorable, cyst bank in poor condition, small area on which cysts are detected, planning a change in use

U2 - bad prospects; Absence or single cysts, low viability, severe changes in use, habitat contamination.

\section{GENERAL EWALUATION}

The overall assessment is determined by the assessment of the lowest classified parameter (population, habitat, perspective)

\section{THE METHOD OF PERFORMING THE RESEARCH}

Habitat maps as well as aerial or satellite imagery can be useful for selecting potential sites for Streptocephalus torvicornis, from which it is possible to infer the presence of small bodies of water and floodplains. To increase the chance of discovering new sites, the test area should be as large as possible. It should be noted that the floodplains undergo natural changes and monitoring studies should be carried out taking into account the possibility of shifting the floodplain in subsequent years.

The first step in population assessment is collecting soil samples from the bottom of the pools or from a periodically flooded area. The samples should be collected so as not to disturb the structure of the bottom of the tank. The soil samples must be representative. The collection site must be selected by systematic sampling, taking account of the terrain and other factors. For example, if the samples are taken from the bottom of a carp pond, they should be collected from the drainage ditch and near the dyke and at various levels of the slope. It is good if the total mass of the samples is not less than $3 \mathrm{~kg}$. Then, the precisely described samples should be transported to the previously prepared laboratory. Separation of cysts from soil elements is made by the sugar flotation method using $50 \%$ sucrose solution and sieves with a mesh size of $100 \mu \mathrm{m}$.

Then, using a binocular, count all Streptocephalus torvicornis cysts from the sample. A randomly selected portion of cysts should be placed in clean, soft water to initiate the hatching process. A petri dish can be used for this. Cysts must be illuminated with a strong light source. The optimal temperature for hatching is $22-25^{\circ} \mathrm{C}$. After 48 hours, calculate the ratio of hatched larvae to all cysts intended for hatching. Cysts from which larvae have not hatched should be re-dried and flooded because some larvae require flooding and drying several times. The larvae should then be transferred to breeding tanks where they will grow up. Subjects may be fed with food in the form of suspensions, e.g. spirulina (Arthrospira platensis), ground with water, wheat flour, baker's yeast. The best food is freshwater algae Chlorella and Scenedesmus. Female-deposited cysts should be aspirated from the bottom with a weekly water change and dried. Cultivation and introduction of cysts to the natural environment is performed in order to compensate for losses resulting from soil sampling, which depletes the natural cyst bank. 
It is also possible to simplify the method and limit it to cyst separation from soil elements and counting. Then it is possible to re-introduce the previously collected cysts into the natural environment. However, with this method, we will not obtain information about the viability of the cysts. There is a potential risk that the dead cysts may persist in the environment for many years, which may overestimate the state of the population.

In the period when the places of occurrence are flooded, an initial assessment of the condition of the habitat may be carried out. Soil samples should be collected in summer or dry winter weather. Best when the soil is dry.

Monitoring should be carried out regularly, every 3 years.

There is a possibility of adapting the developed methodology to the monitoring of other species of large branchiopods occurring in Poland with similar ecological requirements such as:

Branchinecta paludosa (Müller, 1788)

Branchipus schaefferi (Fischer, 1834)

Chirocephalus diaphanus (Prévost, 1803)

Chirocephalus shadini (Smirnov, 1928)

Eubranchipus grubii (Dybowski, 1860)

Lynceus brachyurus Müller, 1776

Lepidurus apus (Linnaeus, 1758)

Triops cancriformis (Bosc, 1801)

Cyzicus tetracerus (Krynicki, 1830)

Limnadia lenticularis (Linnaeus, 1761)

\section{REFERENCES}

Beladjal L., Mertens J. 2003. Interstitial remains for fauna reconstruction of desert pools using fairy shrimp as example (Anostraca). J. Crust. Biol. 23, 9.

Brendonck L., Rogers D.C., Olesen J., Weeks S., Hoeh W.R. 2008. Global diversity of large branchiopods (Crustacea: Branchiopoda) in freshwater. Hydrobiologia 595, 167-176.

Cukier S. 2019. Bioróżnorodność skrzelonogów w ekosystemach wodnych Rybackiej Stacji Doświadczalnej „Łąki Jaktorowskie”. Warsaw University of Life Sciences - SGGW. [in Polish]

Czyż M.J., Woliński P., Gołdyn B. 2016. Cyst morphology of large branchiopod crustaceans (Anostraca, Notostraca, Laevicaudata, Spinicaudata) in western Poland. Biol. Lett. 53, 79-88.

Dulina A.S. 2008. Relation of Branchiopodae Streptocephalus torvicornis to major factors of environment Astrakhan State University. [in Russian]

Dumont' H.J., Mertens' J., Martinez A.M.M. 1995. Historical biogeography and morphological differentiation of Streptocephalus torvicornis (Waga) since the W\&m III-glaciation. Hydrobiologia 298, 281-286.

Dumont H.J., Munuswamy N. 1997. The potential of freshwater Anostraca for technical applications, in: Live Food in Aquaculture, eds. A. Hagiwara, T.W. Snell, E. Lubzens, C.S.Tamaru, Dordrecht, Springer Netherlands, 193-197.

Gołdyn B., Bernard R., Czyż M.J., Jankowiak A. 2012. Diversity and conservation status of large branchiopods (Crustacea) in ponds of western Poland. Limnologica 42, 264-270.

Gołdyn B., Kowalczewska-Madura K., Barałkiewicz D. 2019. Key environmental factors for the conservation of large branchiopods in farmland vernal pools - a case from a Central European diversity hotspot. Crustaceana 92, 613-631. 
Kappas I., Mura G., Synefiaridou D., Marrone F., Alfonso G., Alonso M., Abatzopoulos T.J. 2017. Molecular and morphological data suggest weak phylogeographic structure in the fairy shrimp Streptocephalus torvicornis (Branchiopoda, Anostraca). Hydrobiologia 801, 21-32.

Kraus H., Eder E., Werding B., Sten Møller O. 2004. Cyst Deposition Behaviour and the Functional Morphology of the Brood Pouch in Streptocephalus Torvicornis (Branchiopoda: Anostraca). J. Crust. Biol. 24, 393-397.

Makomaska-Juchiewicz M. (ed.) 2010. Monitoring gatunków zwierząt - przewodnik metodyczny. Warszawa, GIOŚ. [in Polish]

Maeda-Martinez A., Dumont' H.J. 1995. A contribution to the systematics of the Streptocephalidae (Branchiopoda: Anostraca). Hydrobiologia 298, 263-280.

Mertens J., Beladjal L., Dierckens K. 2007. Pheromones inhibit the hatching of diapausing Anostraca (Crustacea: Branchiopoda). Anim. Biol. 57, 1-9.

Ramułt M. 1939. Spostrzeżenia nad występowaniem liścionogów właściwych (Euphyllopoda) w okolicy Krakowa [Observations on the occurrence of large branchiopods in the vicinity of Krakow]. Spraw. Komis. Fizjograf. PAU 13, 261-270. [in Polish]

Rogers D.C. 2013. Anostraca catalogus (Crustacea: Branchiopoda). The Raff. Bull. Zool. 61, 525-546.

Schwentner M.,Timms B.V., Richter S. 2012. Flying with the birds? Recent large-area dispersal of four Australian Limnadopsis species (Crustacea: Branchiopoda: Spinicaudata). Ecol. Evol. 2, 1605-1626.

Vanschoenwinkel B., Gielen S., Seaman M., Brendonck L. 2008. Any way the wind blows - frequent wind dispersal drives species sorting in ephemeral aquatic communities. Oikos 117, 125-134.

Zierold T. 2006. Morphological variation and genetic diversity of Triops cancriformis (Crustacea: Notostraca) and their potential for understanding the influence of postglacial distribution and habitat fragmentation. TU Bergakademie Freiberg.

\title{
PROPOZYCJA MONITORINGU GATUNKU Streptocephalus torvicornis (Waga 1842) W POLSCE
}

\begin{abstract}
Streszczenie. W pracy została przedstawiona propozycja metod monitoringu gatunku Streptocephalus torvicornis należącego do dużych skrzelonogów. Gatunek ten występuje w niewielkich okresowych zbiornikach wodnych. Obecnie znane jest tylko jedno stanowisko występowania S. torvicornis w Polsce. Wiele gatunków dużych skrzelonogów uważanych jest za zagrożone wyginięciem. Ich obserwacja w środowisku jest utrudniona przez okresowy charakter występowania form dorosłych. Zaproponowana metoda oceny stanu populacji opiera się na analizie próbek gleby pod względem obecności cyst przetrwalnych. Do oceny stanu siedliska może służyć: obecność roślinności wskazującej na astatyczny lub efemeryczny charakter zbiornika, poziom sukcesji drzew i krzewów, obecność ryb, obecność potencjalnych źródeł zanieczyszczeń. Zaproponowane metody są uniwersalne; mogą być zastosowane do monitoringu innych gatunków skrzelonogów. Regularny monitoringu może przyczynić się do poznania kolejnych miejsc występowania oraz umożliwi skuteczną ochronę gatunku S. torvicornis w Polsce.
\end{abstract}

Słowa kluczowe: Branchiopoda, bank cyst, metody monitoringu. 
